\title{
Gastric metastasis of acrolentiginous melanoma
}

\section{Selma El Kadiri', Sara Elloudi', Rhizlane Chaoui', Zakia Douhi' ${ }^{1}$, Hanane Bay Bay ${ }^{1}$, Fatima-Zahra Mernissi ${ }^{1}$, Leila Chbani ${ }^{2}$, Imane Gouzi ${ }^{2}$}

\author{
${ }^{1}$ Departement of Dermatology, CHU Hassan II, Fez, Morocco, ${ }^{2}$ Anatomopathology Department, CHU Hassan II, Fez,
} Morocco

Corresponding author: Dr. Selma El Kadiri, E-mail: elkadiri-s@hotmail.com

The stomach is a rare site of melanoma metastasis [1]. We report a base of a 63-year-old patient with a history of acrolentiginous plantar left melanoma with surgical, and lymphatic node excision 5-years ago who presented to the hospital complaining of intermittent epigastralgia and a transit-metastasis. A body scanner was performed and showed two hepatic nodules with antro-fundic thickening. An esophago-gastro-

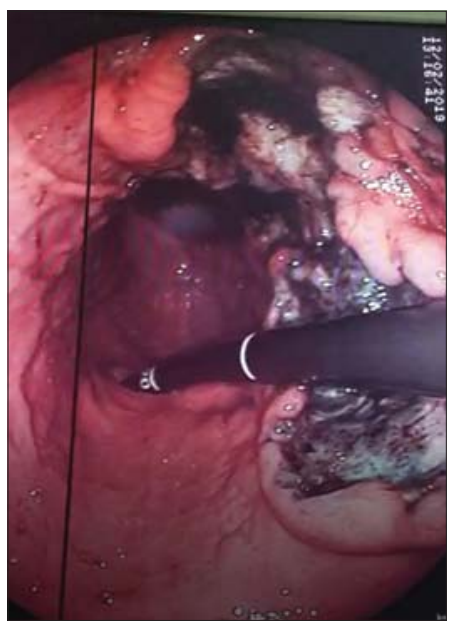

Figure 1: Endoscopic image of pigmented crater involving the lesser curvature.

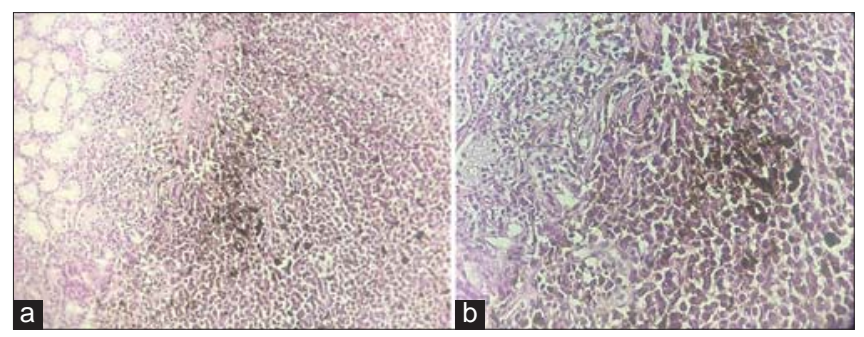

Figures 2: $(a$ and b) H\&E stained slide at $100 x$ and 200x magnification demonstrating pigment deposition can be seen within the cells of the malignant melanoma. duodenoscopy showed a 6-centimeter pigmented crater involving the lesser curvature with raised and irregular borders (Fig. 1). Pathology revealed that the stomach was infiltrated by a population of atypical pigmented tumor cells (Figs. 2a and 2b). The cells expressed the melanoma marker HMB-45 and melan-A on immunohistochimical stains confirming the diagnostic of gastric metastasis of melanoma. Serum LDH level was elevated. The patient's file was discussed in a multidisciplinary consultation meeting and palliative dacarbazine-type chemotherapy was adopted for this patient.

\section{Consent}

The examination of the patient was conducted according to the Declaration of Helsinki principles.

The authors certify that they have obtained all appropriate patient consent forms. In the form the patient(s) has/have given his/her/their consent for his/ her/their images and other clinical information to be reported in the journal. The patients understand that their names and initials will not be published and due efforts will be made to conceal their identity, but anonymity cannot be guaranteed.

\section{REFERENCE}

1. Liang KV, Sanderson SO, Nowakowski GS, Arora AS. Metastatic malignant melanoma of the gastrointestinal tract. Mayo Clinic Proceedings. 2006;81:511-16.

Copyright by Selma El Kadiri, et al. This is an open-access article distributed under the terms of the Creative Commons Attribution License, which permits unrestricted use, distribution, and reproduction in any medium, provided the original author and source are credited.

Source of Support: Nil, Conflict of Interest: None declared.

\footnotetext{
How to cite this article: El Kadiri S, Elloudi S, Chaoui R, Douhi Z, Bay Bay H, Mernissi F-Z, Chbani L, Gouzi I. Gastric metastasis of acrolentiginous melanoma. Our Dermatol Online. 2020;11(e):e12.1.

Submission: 16.01.2020; Acceptance: 13.02 .2020

DOI: 10.7241 /ourd.2020e.12
} 